\title{
Psychosocial adjustment and physical health in children of divorce
}

\author{
Rui A. Nunes-Costa, ${ }^{1}$ Diogo J. P. V. Lamela, ${ }^{2}$ Bárbara F. C. Figueiredo ${ }^{3}$
}

\begin{abstract}
Objective: To review the literature on the effects of parental divorce over the psychological maladjustment and physical health problems in children of divorced parents, thus contributing to the integration of existing scientific knowledge based on the biopsychosocial model of the impact of divorce on children's physical health as proposed by Troxel and Matthews (2004).

Sources: Review of the literature using MEDLINE and PsycInfo (1980-2007) databases, selecting the most representative articles on the subject. Special attention was paid to contributions by internationally renowned investigators on the subject.

Summary of the findings: Divorce may be responsible for a decline of physical and psychological health in children. The developmental maladjustment of children is not triggered by divorce itself, but rather by other risk factors associated with it, such as interparental conflict, parental psychopathology, decline in socio-economic level, inconsistency in parenting styles, a parallel and conflicting co-parenting relationship between parents and low levels of social support. Such risk factors trigger maladjusted developmental pathways, marked by psychopathological symptoms, poor academic performance, worst levels of physical health, risk behavior, exacerbated psychophysiological responses to stress and weakening of the immune system.

Conclusions: Clear links were observed between experiencing parental divorce and facing problems of physical and psychological maladjustment in children. Divorce is a stressor that should be considered by health professionals as potentially responsible for maladjusted neuropsychobiological responses and for decline in children's physical health.
\end{abstract}

J Pediatr (Rio J). 2009;85(5):385-396: Divorce, children, health, interparental conflict, immunology, stress.

\section{Introduction}

In the late 1960s, Levine et al. ${ }^{1}$ developed an experimental animal model showing that early stress experiences may have effects over hormonal stress responses in adulthood. However, significant results have been found in investigations with humans regarding the relation between exposure to an environment rich in stressors throughout the first years of life and psychophysiological vulnerability in later years. ${ }^{2-4}$

The experience of parental separation results in a decline in individual and family well-being in children. The literature is consistent in pointing out that most children present decreased developmental outcome in the

1. Licenciado, Ciências Psicológicas. Mestrando, Mestrado Integrado em Psicologia Clínica, Universidade do Minho (UM), Braga, Portugal.

2. Doutorando, Programa Doutoral em Psicologia Clínica, UM, Braga, Portugal. Professor assistente, Escola Superior de Educação, Instituto Politécnico de Viana do Castelo, Viana do Castelo, Portugal.

3. Doutora, UM, Braga, Portugal. Professora associada, Departamento de Psicologia, UM, Braga, Portugal. Coordenadora, Unidade dos Estudos do Divórcio \& Intervenção, UM, Braga, Portugal.

This study was carried out at Departamento de Psicologia, Universidade do Minho (UM), Braga, Portugal.

No conflicts of interest declared concerning the publication of this article.

Suggested citation: Nunes-Costa RA, Lamela DJ, Figueiredo BF. Psychosocial adjustment and physical health in children of divorce. J Pediatr (Rio J). 2009;85(5):385-396.

Manuscript submitted Jan 06 2009, accepted for publication Mar 042009

doi:10.2223/JPED.1925 
two years following marital dissolution. ${ }^{5}$ Such adaptation problems, however, tend to be ephemeral and may not have significant impact in the child's future developmental pathway. ${ }^{6}$ A conflicted parental relationship is, in itself, a risk factor enough to generate a high level of stress. However, most investigations in the area suggest more risk factors for a negative adjustment in the marital dissolution process, such as alterations in the family socioeconomic level, less frequent contact with the parent who does not have parental rights, and interparental conflict. $5,7,8$ All these factors, usually transversal to divorce, may have an impact over stress response and, later on, over the physical and psychological health of the children implicated in this reorganization of the family system.

Although there is empirical evidence on the impact of marital dissolution over physical health, the scientific community has developed very few conceptual proposals of correlation between both constructs. One of the rare theoretical proposals has been presented by Troxel \& Matthews ${ }^{9}$; namely the biopsychosocial model of the impact of marital dissolution on children's physical health (Figure 1). In summary, the model proposes that divorce is a family stressor which causes, on one hand, disorganization of parental practices and, on the other hand, a negative impact over the family economic security. When associated to factors of biological, family, interpersonal and social vulnerability, these dimensions will contribute to emotional dysregulation and insecurity in children. Such emotional instability is the result of developmental variations on affectional, behavioral and cognitive levels. These alterations - such as, the appearance of internalizing and externalizing symptomatology, decline or inhibition of stress-management strategies and stress-induced cognitive bias - will translate in health-risk behaviors and in the neuropsychobiological stress responses. As a consequence, these physical health problems are reflections of the significant developmental transformations to which children must respond in face of a family change.

This article aims to review the literature regarding the impact of parental divorce over children's physical and psychological health, in order to respond to the needs of scientific update of pediatricians and other health care professionals. The biopsychosocial model of Troxel \& Matthews $^{9}$ was selected as the conceptual guideline for

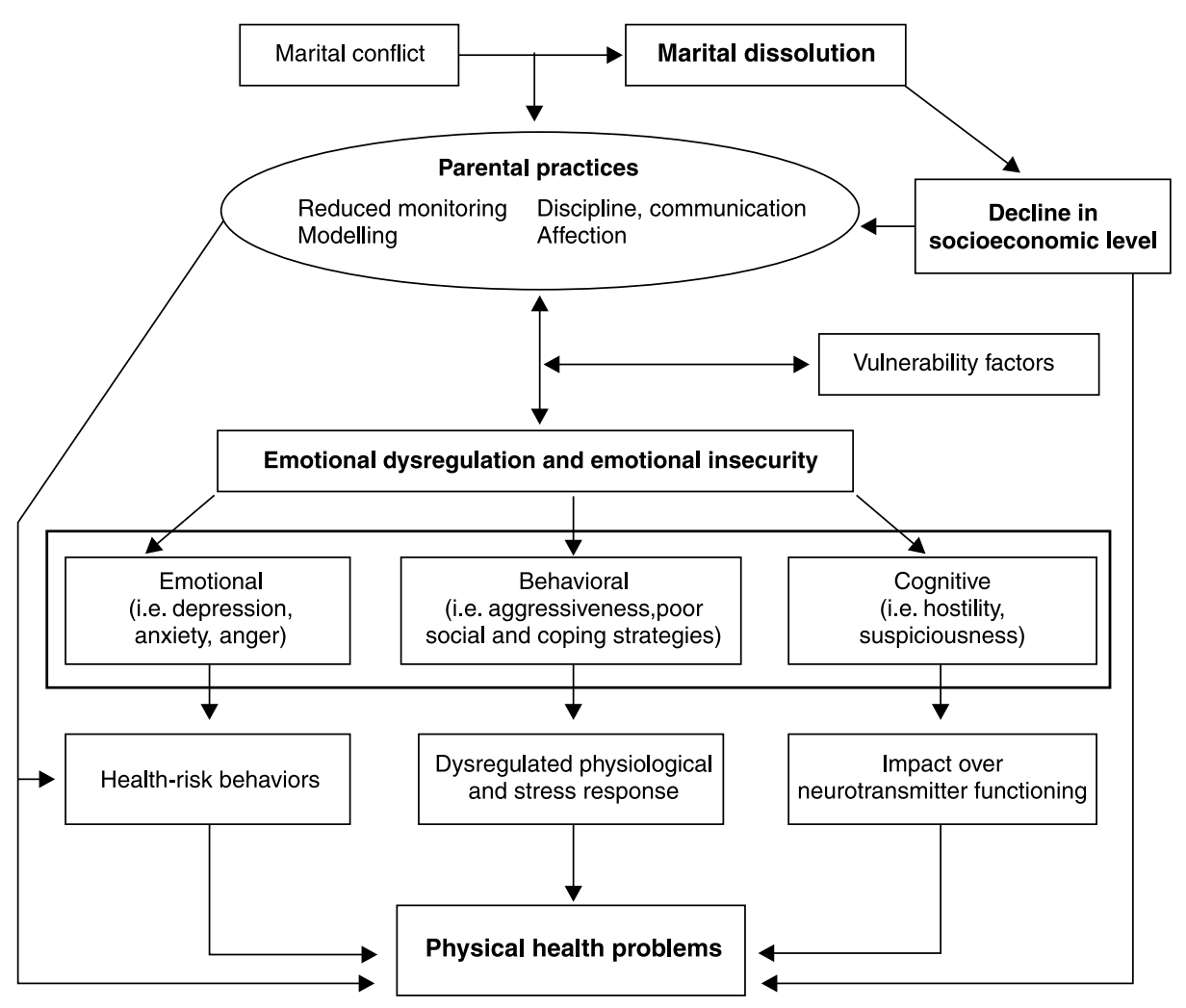

Figure 1 - Biopsychosocial model of the impact of marital dissolution on children's physical health as proposed by Troxel \& Matthews ${ }^{9}$ (adapted) 
the organization of this review. The first part of this article is dedicated to vulnerability and risk factors which interact in the (dis)adaptive behavioral responses of children to parental divorce, with special focus on children's individual characteristics, the family financial situation, parental styles and quality of the coparental alliance, individual characteristics and levels of adjustment of parents, and interparental conflict. After that, the impact of divorce is assessed based on children's academic achievement, externalizing/internalizing disorders, stress levels, physical health and immunologic response. The main conclusions are then summarized, and guidelines are proposed for future investigations.

\section{Vulnerability and risk factors}

In a metanalysis including 92 studies conducted from 1950 to 1980 , Amato \& Keith ${ }^{8}$ have tried to identify the reasons why divorce has negative effects on children, comparing children of intact families with children who had experienced parental divorce. The results, consistent with later studies, underscore the delimitation of five main risk factors in children's adjustment response to divorce: i) factors intrinsical to each child; ii) decline in financial security following divorce; iii) psychopathological pictures of parents, depression is especially relevant; iv) conflicted or uncommitted co-parenting; and $v$ ) intensity, tone and frequency of interparental conflict before and during the period of marital dissolution.

\section{Children's individual characteristics}

Hetherington et al. 5,10-12 have consistently emphasized two dimensions which are intrinsic to each child, during the process of adapting to separation: temper and development level. Children who have an easy temper, are intelligent, responsible and socially sensible are those who show the best capacity to positively adapting to this family transition. ${ }^{5}$ For some time the literature has been supporting the hypothesis according to which dimensions such as selfesteem, cognitive competence and autonomy of children, along with social support systems, are positively associated to children's adaptability. According to recent investigation, the quality of adaptation to parental divorce seems to also be associated to the child's developmental stage at the moment of marital dissolution, although some caution must be exercise in regarding this correlation. ${ }^{11}$ Some studies have concluded that preschool age children are subject to higher ecological and developmental risks for disadapted social and emotional pathways in comparison to older children. ${ }^{14}$ Children's immature cognitive and emotional structures cause them to be, on one hand, less capable of realistically assessing the causes, processes, and consequences of divorce and, on the other hand, centralize in themselves the responsibility for the marital disruption, in addition to their inability to seek support from extra-family sources in order to decrease their level of stress. Therefore, when isolating the developmental level from other moderating variables, it has been observed that the higher and more integrated the level of development, the better the index of child adaptation to parental divorce. ${ }^{7}$

\section{Family financial security}

Marital dissolution often leads to a decline in financial security. Parents who have maintained custody of their children experience drastic decline in financial resources available to provide for the family's needs. Indeed, the decline in financial security is one of the main risk factors for a child's adaptation parental divorce, once a reduction in family income may reflect upon their own real and subjective well-being, due to the reduction of resources available for healthcare, education, after-school activities, access to cultural and entertainment goods, and purchase of everyday products. ${ }^{15,16}$ Beyond immediate consequences on the perceived quality of life levels, the financial hardships caused by divorce, if persistent and long-lasting, may also have a long-term impact, once they prevent children from engaging in activities which are essential to their cognitive and social development. In a recent study, Fischer ${ }^{17}$ has concluded that a high income fathers contribute to intensify the negative consequences of divorce in children's academic performance, while high income mothers - the mother being granted custody in most cases - are associated to milder adverse effects of the divorce. However, other studies have shown that children of divorced parents who have not experienced financial impact present the same results, in terms of adaptation level, as children of intact families. ${ }^{15,18}$ The financial security of the family, most importantly that of the parent who has been granted custody of the child, is a protective factor for the child's development.

\section{Parental styles and coparental relationships}

According to the biopsychosocial model of Troxel \& Matthews, ${ }^{9}$ alterations in family structure force children to interact with a context of psychosocial stressing factors which can lead to risk for their physical health. Characteristics of parental behavior have been associated to children's levels of adjustment; however, the impact of parental styles in the adaptive pathways of children of divorced parents have not been the subject of enough empirical investigation, although some research has shown that parental practices are particularly critical and could mediate the effects of family instability over children. ${ }^{19}$

Campana et al., ${ }^{20}$ in their innovative study on parental styles and the global adaptation of children to marital dissolution, present relevant conclusions on the topic. First, a democratic parental style shared by both parents 
has a huge impact over the chances of well-adjustment of children to divorce, a pattern which is marked by lower prevalence of depression, higher self-esteem levels and fewer reports of oppositional behavior Second, mothers with a democratic parental style accept and encourage shared custody with their ex-spouses. Finally, the worst adjustment results in children whose parents do not share a democratic parental style are due to the child's difficulty in emotionally managing the mixed educational messages from parents, which increases the rate of internalizing disorders.

Indeed, some parents present difficulty in maintaining educational consistency and a democratic parental style in the initial stages after marital disruption, ${ }^{21}$ once they are often focused on their own adjustment to the new family reality. Co-parenting is another essential concept in explaining children's adaptation to parental divorce, and is conceptualized as the father/mother dyad relationship in the planning and execution of a joint parental plan for their children. ${ }^{22}$ In summary, this concept is defined by the joint and reciprocal involvement of both parents in the education, background and decision-making about their children's lives. ${ }^{23}$ Cooperative parents prioritize their children's well-being, while creating and maintaining a constructive relationship, with new, more flexible boundaries between one another

According to Maccoby et al., ${ }^{24}$ co-parenting is not limited to sharing responsibility for the children's education, once it implies that parents effectively cooperate by supporting each other's decisions and adopting them in their own individual relationship with their children. These authors have identified three variations in co-parenting: cooperative co-parenting, conflicted co-parenting, and uncommitted co-parenting, and recently divorced families are more exposed to the risk of uncommitted co-parenting relationships. Beyond the physical distance between the parents, difficulties in isolating the marital relationship of the past from the co-parenting relationship of the present and the reduced involvement of the parent who has not been granted custody in the child's life ${ }^{27}$ also contribute to parental lack of commitment.

Investigation shows that most divorced parents present with a disruptive co-parenting pattern, marked by high levels of conflict or lack of commitment in the children's education, which is translated by parallel, detached parenting practices, thus undermining the child's perception of the parental alliance and contributing to parental conflict. ${ }^{28}$ Such loss in parental cohesion causes grave consequences in children's development, once children of divorced parents are exposed to and involved in parental practices that lack a common guideline, thus increasing the probability of triangulation across generations of the family. As an example of this, Macie ${ }^{23}$ has identified that $66 \%$ of divorced families presented clear and powerful father/mother-child alliances, which was also associated to high rates of anxiety in the children involved in this tangled web of disruptive family relationships.

Co-parenting studies have, therefore, come to two essential conclusions: i) the better and higher the cooperation, respect and communication between parents in conducting their children's education, the better the adjustment of children will be, and these elements operate as genuine protective factors within families ${ }^{6,29}$; and ii) the involvement of the parent who has not been granted custody, when marked by strong and consistent emotional bond and a democratic parental style can influence the well-being of children in dimensions such as academic performance or health condition. ${ }^{26}$

\section{Parental psychopathology and psychosocial maladjustment}

The literature is globally consistent in showing that parental depression, a common event during and following the divorce process, is a risk factor in internalizing (such as anxiety and depression) and externalizing (such as opposition) disorders in children and adolescents. 5,30 The existence of parental depression increases the probability of decrease in material and emotional care of children. 15,31 Mothers with depressive symptoms are more likely to display negative emotions, negligent behavior, hostile behavior, less educational consistency, less positive parental behavior, less care for children's health, less emotional availability and engage in higher risk parenting behavior. ${ }^{32}$ As a result, children of depressed or anxious divorced parents present a higher probability of developing depression and anxiety, more oppositional behaviors, lower self-esteem, less social behavior, worse academic performance, higher attention deficits and more challenging interpersonal relationships. ${ }^{33}$

Depressive pictures in the mother also have indirect effects on children's maladjustment. Depressive symptoms in parents have even predicted the role inversion situation within families, with children providing emotional care and support for the depressed parent. Investigation has shown that this situation does not promote adaptive development for the children who are involved in this family interaction pattern. ${ }^{34}$ Therefore, the reorganization of the family after marital dissolution may drive parents to assign the role of emotional provider, which was previously assigned to the ex-spouse, to children, thus intensifying adaptation problems, anxiety disorders, psychophysiological reactivity and oppositional behaviors in children. 35

\section{Interparental conflict}

The interparental conflict common to the divorce process and to the period which precedes it is indicated by the metanalysis of Amato7,8 as the greatest stressor for children. Nowadays it has been empirically established 
that parental conflict is the main dimension involved in children's maladjustment to divorce. ${ }^{28}$ In other words, an environment of interparental conflict, regardless of how it manifests - anger, hostility and suspiciousness, aggressive language, physical aggression, difficulty cooperating in care of and communication with children 27 - creates an atmosphere in which children experience high levels of stress, dissatisfaction and insecurity. ${ }^{36-38}$ Other studies demonstrate that interparental conflict results in deterioration of parentchild relationships. 39,40 However, divorce may be a possibility to evade an interparental conflicted atmosphere, although in most cases the reduction in the level of conflict tends to become evident only after the first year post-divorce. 6

Highly conflicted parental dyads often transfer these disruptive interaction patterns into judicial litigation. The children with the worst levels of adjustment are those whose parents are involved in court battles over parental rights regulation during long periods. ${ }^{41}$

In most cases parental practices and routines disturbed by the high interparental conflict reflect on permissive and inconsistent discipline, emotional volatility, high levels of educational hostility and impulsivity, lower responsivity and emotional availability. Interparental conflict after divorce is therefore a driver for parental styles that clearly compromise children's adjusted development, such as the negligent, permissive or authoritarian styles. ${ }^{20}$

Parental relationships between the former marital dyad are regarded as having not only direct effects over children's psychological functioning, but also indirect effects, mediated by the effects of parenting quality. Psychological functioning is equated as the result from child adjustment and inteparental conflict, therefore establishing itself as a lever for developmental vulnerability, resilience or competency processes.
Moderating variables in this equation are family ecology (such as family environment, parental degrees of adaptation, socioeconomic levels) and characteristics associated to children (such as intelligence, temper, age, gender). Schick ${ }^{42}$ has found that children's perception of the parental conflict destructiveness operated as a mediator for the presence/absence of psychopathological symptoms in children: the greater the perceived destructive interparental conflict, the greater the risk of adjustment problems in children. Children involved in highly conflicted parental divorce inherently present more intense externalizing behavior, if compared to children who experience low litigation conflict. 28

Therefore, we understand that the configuration of children's pathway of (mal)adjustment to parental divorce is the result of a complex contextual interaction, in which the child is also in possession of characteristics that mediate the impact of the said process over their own development. The literature for this orientation is abundant, with studies that show the attenuation factors intrinsic to children. Children's age at the moment of their parent's official separation is highly associated to the type and intensity of their reaction to the marital dissolution between parents (Table 1 ).

\section{Impact of divorce over children's development}

Children of divorce with low levels of hostility and conflict in co-parenting present good levels of adjustment, comparable to those of children of intact families with low levels of conflict. Studies show that the degree and quality of children's functioning are not exclusively associated to the type of family structure, but instead to the quality and tone of the relationship between the marital/parental dyad.

Table 1 - Risk factors for physical and psychological health problems in children of divorce

Temperamental and developmental factors in children (such as self-appeasement, age, prematurity, and cognitive development);

High levels of conflict between parents during the marriage;

Maintenance of high levels of conflict after divorce;

Low socioeconomic level;

Parental psychopathological conditions;

Low levels of adjustment to parental divorce;

Less educated mother;

Low emotional and instrumental support;

Decline in financial resources available;

Parental health risk behaviors (such as tobacco addiction, alcohol abuse, deregulation of routine and nutritional quality). 
Hetherington ${ }^{26}$ shows, for instance, that pre-adolescents of divorced parents achieve developmental results superior to those of pre-adolescents of intact families with high levels of conflict.

The main effects of divorce over the physical and psychological adjustment of children to parental divorce are considered over the next section.

\section{Academic performance and interpersonal relationships}

Along the past decades, some studies have shown that children of divorce present lower academic motivation and performance if compared to children of intact families. ${ }^{43}$ In more concrete terms, children of divorced parents would be less capable of finishing school projects, face more challenges concentrating in complex tasks, present worse academic results in languages and mathematics and lower level of responsibility. 44

Some authors suggest that decreased parental involvement in children's academic life is the main factor behind decline in school results. In most cases, marital dissolution leaves the discussion of school topics, monitoring study at home and reviewing school tasks under the responsibility of the parent who has been granted custody. 45 Marital dissolution forces families to adopt a new structure and often requires parents to increase their working hours for additional income, thus making it harder for divorced parents to get involved in their children's school activities. Indeed, Bertram ${ }^{44}$ has discovered that poor academic performance in children of divorce were, on one hand, associated to poor parental involvement and, on the other hand, correlated to reduced levels of parental adjustment to divorce.

\section{Internalizing and externalizing disorders: a psychophysiological and behavioral perspective}

Children who are continually exposed to episodes of excessive interparental conflict present higher psychophysiological, behavioral, cognitive and emotional reactivity. ${ }^{28}$ Such high levels of reactivity are associated to the increase and accumulation of situations that represent relative risk for the development of maladjustment to divorce in children. The next step in the study was to describe the relation between parental interaction, physiological reactivity and children's internalizing and externalizing responses.

A maladjusted pathway following parental divorce, added to the mediating variables of the child and to the availability of environmental resources, could result in a deviant behavioral pattern of interaction with the parents, and, later on, with other people.

Supported by this explanatory basis, some evidences of longitudinal studies report that individuals who have experienced parental divorce present more internalizing and externalizing problems than those who have never experienced parental divorce. 46

Internalizing disorders are defined as the set of traces such as depression, isolation or anxiety. ${ }^{47}$ Adults who, as children, were exposed to negligent parental care or chronic stress situations and who present any symptoms of an internalizing disorder present baseline cortisol values higher than average, especially at the end of the day. ${ }^{48-50}$ The study by Cicchetti \& Rogosch ${ }^{51}$ found similar results in school-age children, who had also been diagnosed with some type of internalizing symptom. Schiefelbein \& Susman, 52 in turn, in their longitudinal study, have observed alterations in the normative cortisol levels in children associated with anxiety problems in adolescence and adulthood (especially in women). Such high cortisol levels are related to hypothalamo-pituitary-adrenal axis dysregulation by a mechanism of downregulation in the feedback process. In other words, a decrease in the number of receptors for stress hormones is observed in the hypothalamus and pituitary gland. Such decrease in the number of receptors is implicated in a type of "dysregulated cycle" described by Niehoff 49 as "a selfperpetuating and self-defeating cycle in which stress causes cortisol levels to rise, high levels of cortisol reduce neuronal sensitivity, non-reactive neurons lose control over the hypothalamo-pituitary-adrenal axis, and the suprarenal gland, unsupervised, continues to excrete excess cortisol" (p. 292).

From a psychosocial perspective on internalizing pathways of children, the investigation shows that lack of adaptive behavior from the mother is generally associated to permissive boundaries in the parental subsystem, which gives way to parentification and consequent increase of externalizing disorders in children of divorce. Depressed mothers are likely to establish a relationship in which they confide in their children, which tends to be associated to depression issues in children. ${ }^{53}$ On the other hand, children involved in highly conflicted divorces present are two to five times more likely to present behavioral disorders and emotional dysregulation, when compared to normal samples. 54

Externalizing disorders, in turn, encompass behaviors regarded as "acting out", such as addictive, impulsive or hyperactive conducts or antisocial behaviors. Malone et al. ${ }^{55}$ suggest that male children who experience parental divorce are more likely to present externalizing behavior at school, especially during the year of the divorce, with a decrease to baseline levels one year after marital disruption, if compared to female children. Such conducts are usually associated to low cortisol production. Studies show, however, that this is not a linear relation, 49,56 once high cortisol levels can be observed in children diagnosed with externalizing disorders. 


\section{Psychophysiology and physical health}

According to the model proposed by Troxel et al., ${ }^{9}$ the effects of the chronicity in stress responses over health must be taken into account, and, once the divorce experience is potentially a source of acute and chronic stressors, it is vital that one understands the implications of such event over health and its role in the increase of psychopathological symptoms in children of divorce, both in the short and long-run.

\section{Stress and psychophysiology}

The subjective perception of a stress-inducing element in the environment activates a cascade of biological actions in order to produce an organic survival reaction from an evolutionary perspective. Once it reaches the thalamus, information from the various sensorial channels is forwarded to the cortical and subcortical structures responsible for the emotional assessment of stimuli, namely the prefrontal cortex, amygdala, hippocampus, anterior cingulate cortex, and insular cortex.

After assessing an event as negative - parental divorce, in the present case -, the hippocampus activates the hypothalamic-pituitary-adrenal (HPA) axis. The paraventricular nucleus in the hippocampus release arginine vasopressin (AVP) and corticotropin-releasing factor (CRF) ${ }^{57}$ which, in turn, activates the amygdala, 58 nucleus accumbens, sympathetic nervous system, and finally the pituitary-adrenal axis. The CRF causes the anterior pituitary to produce adrenocorticotropic hormone (ACTH) and beta-endorphins. After its production, the ACTH enters the circulatory system (achieving maximum increment at approximately 10-15 minutes) and activates the suprarenal cortex. The suprarenal gland is in charge of producing glucocorticoids (in the human species, cortisol), whose maximum increment is achieved only after 15-30 minutes, 59 and mineralocorticoids (aldosterone). ${ }^{60}$ The function of cortisol is mainly to reinforce the formation of glucose from amino acids and in anti-inflammatory and immunosuppressants (such as suppressing cytokines). This is, however, a pluripotent hormone which acts in different tissues, regulating countless aspects of the organism's metabolism, functioning and growth.

This system also causes the adrenal medulla to secrete the catecholamines noradrenaline and adrenaline, thus gathering the organism's energies for action, preparing it to imminent flight from potentially adverse situations (such as interparental conflict and parental inconsistency), a process which is reflected by increased heart rate, blood pressure, hyperhidrosis, peripheral vasoconstriction, increased sensorial, pupil and airway activity, in addition to inhibition of functions which are irrelevant at a time of flight or adjustment, such as digestion or growth hormone (GH) action. These are quick and ephemeral responses which allow for an increase of attention levels, due to an activation of the mesocortical dopaminergic system, especially its projections over the medial prefrontal cortex. 59

The stress response to parental divorce, efficient and physiologically flexible, is adaptive on the short-run. However, once continually subject to homotypical or severe stimuli, children's organisms suffer a drop in their capacity for feedback response, establishing a positive correlation with the risk of disease. This is expressed, for instance, in the increased number of behaviors associated to depressive states, insulin-resistant diabetes, hypertension, immunosuppression, reproductive problems, and Cushing's syndrome. ${ }^{61}$ When children are subject to chronic stress related to their parents' marital dissolution, several studies suggest a significant increase in dendritic arborization in the basolateral nucleus of the amygdala, capable of inducing atrophy of the pyramidal neurons of the hippocampus, especially in the CA3 region. 62,63 This, in turn, suggests that chronic stress can lead to unbalanced hypothalamopituitary-adrenal axis, with gradual loss of inhibitory control of the pituitary and a more intense exciting action of the amygdala.

Through several feedforward cycles, during which cortisol causes a boost in cortisol production, the concentration of stress hormones in the blood is finely adjusted to the requirements of the stress-inducing situation, a process which can lead to a state of sleeplessness and hyperreactivity. The hippocampus, as the brain region with the most glucocorticoid receptors, is also an extremely sensitive region to neurotoxic concentrations of such substances. ${ }^{64}$ Excessive exposure to cortisol results in structural and functional alterations in the hippocampus. ${ }^{65,66}$ The medial prefrontal cortex and the prelimbic cortex also seem to undergo structural reorganization after continual cortisol stimulation, as observed in the hippocampus. It is estimated that such alterations are responsible for a $40 \%$ reduction in this region's inputs, which may be associated to outputs from the amygdala during a period of continuous stress. ${ }^{66}$

\section{Stress and immunology}

Most studies with humans on the effects of stress, in naturalist context, suggest that, in face of stressinducing situations (such as parental divorce), the immune system displays signs of decreased competence due to the innervation of lymphoid tissue, both by sympathetic projections and by parasympathetic nervous projections. ${ }^{67}$ Such effect implies a decrease in NK lymphocyte activity 68 ; proliferation of lymphocytes 69,70 ; lymphocyde cytocity 71 ; and increased number of herpes virus antibodies. 69,72 Studies in laboratorial contexts with humans also seem to suggest the same types of results. ${ }^{73}$

However, as shown by studies on the effects of mood 74 or other stress-reduction interventions, ${ }^{59}$ the immune 
response may vary positively, depending on the individual differences (such as coping strategies, personality and behavioral patterns), mood, or social support network.

In contrast with the most important and oldest investigations in the field of psychoendocrinology, recent laboratory evidence reveal a positive association between laboratory exposure to stress-inducting factors and immune response against pathogenic agents. ${ }^{75}$

\section{Stress, divorce and immunology}

Divorce alone does not increase the vulnerability for diseases on the long-run, unless it is experienced in a negative way (for example, associated to interparental conflict and a depressive psychopathology in parents) or leads to losing touch with one of the parents. ${ }^{9}$

Reports of interparental conflict are associated to an increase in the search for health services ${ }^{76}$ and to an increase in somatic symptoms and physical disease both on the shortrun 77,78 and on the long-run. ${ }^{79}$ Parallel to these records, Ballard et al. ${ }^{80}$ have found repercussions on a physiological level in children of conflicted families, namely the increase of blood pressure and of catecholamines in the urine. ElSheikh \& Harger ${ }^{81}$ have recently demonstrated that children of highly conflicted parents present with increased cardiac reactivity when exposed in laboratory to audio recordings of arguments. Likewise, another study reports high levels of cortisol on the blood stream of children used to parental conflict and rare cortisol peaks in response to punishment and argument situations. 82 Parental conflict also interferes with the parasympathetic response, probably associated to disadaptive interactions with the environment. ${ }^{83}$

The long-term relation between disruption in caretaking, especially when associated to significant reduction in the time of contact with one of the parents and to physiological functions, is mainly described in terms of increased blood pressure 84 and alterations in the hypothalamo-pituitaryadrenal axis. ${ }^{2}$ On this level, however, Saler \& Skolnick ${ }^{85}$ argue that long-term negative repercussions increase when the quality of the relationship with the parent who is present in the child's everyday life is compromised.

As previously mentioned, depression associated to a divorce process is also a risk factor in internalizing/ externalizing disorders in children and adolescents. ${ }^{30}$ However, the repercussion of depressive psychopathology of parents over the physical health and physiological response of children is not yet clear either in the short-run or in the long-run. Some studies have been designed with the purpose of making this relationship more clear, showing high baseline cortisol levels in children of depressed mothers, 86,87 as well as exacerbated cortisol responses in physiological responses to stress. 88,89

In summary, a solid set of evidence has been gathered, focusing on the effects of divorce over children's physical health and psychosocial adaptation. Most of these studies have found a significant relation between divorce and risk factors associated to it, with less adjusted developmental results in children of divorce. As described by the model of Troxel \& Matthews, ${ }^{9}$ this review has presented and described the psychobiological mechanisms responsible for the negative reflection of the psychosocial stressor in question over physical health. As a conclusion, the main consequences of marital dissolution over the health and health behaviors in children of divorced parents are presented in Table 2.

\section{Final remarks}

This article has described the impact of divorce over the psychological development, physiological stress responses, physical health and psychopathology in children.

Table 2 - Main conclusions over the impact of parental divorce over children's physical health

Increased risk of physical injuries, disease, hospitalization, somatization, and early mortality associated to parental divorce $90-92$;

Increased health-risk behaviors, such as substance, tobacco, and alcohol abuse following parental divorce ${ }^{91,93-97}$;

Dysregulation of nutritional patterns and sleep patterns ${ }^{98}$;

Difficulty in sphincter training 99,100 ;

Greater vulnerability to obesity, caused by the effective decrease in parental monitoring ${ }^{101}$;

More vulnerability to respiratory diseases ${ }^{102}$;

Increased probability of early engagement in sexual activity and adolescent pregnancy ${ }^{103,104}$;

Lower frequency of access to health care due to decreased parental responsiveness as one of the causes of higher prevalence of physical health problems ${ }^{105}$;

Parental divorce associated to chronic health conditions (hypertension, asthma, insomnia) in adultulthood ${ }^{106,107 .}$ 
The conclusion is that psychopathological behaviors of children could have been generated in a conflicted family environment, marked by parental practices unsuitable for their demands, as a result of a disadaptive family transition. Such environment, rich in chronicity-susceptible stressors, easily interferes in the physiological response to stress, which, in turn, has an impact over children's physical 46,55 and psychological health.

However, this review does not primarily aim to raise conceptual hypothesis to explain the visible relations between these dimensions. This topic is fairly recent in the field of investigation, which is why there are no transversal or longitudinal studies grouping and analyzing the transaction between the said variables. As a consequence, in the future it will be necessary to develop studies with more encompassing methodological designs, that aim to study the interconnections and causality processes between separation, developmental level of children, psychophysiological substrates of stress, physical health levels and psychopathological symptoms, so as to contribute to the empirical knowledge on the impact of divorce over children's developmental pathways.

Children's psychological development is not affected by the divorce itself. Clarke-Stewart et al., for instance, have found that, in a sample consisting of children of up to 3 years old, children of intact families presented better performance in social and cognitive abilities, quality of attachment, and less behavioral problems, when compared to children of divorced parents. However, when controlling the variables mothers' educational level, level of interparental conflict, and family financial condition, developmental differences were significantly reduced, so that no difference was observed between children of the two groups. ${ }^{108}$ Guided by this line of investigation, several studies have reinforced and supported the hypothesis that divorce itself is not an automatic guarantee of maladjustment; instead, the variables associated to family ecology are responsible for causing, maintaining or intensifying maladjusted pathways, rather than divorce as an isolated event. ${ }^{109}$ Marital dissolution, on the contrary, can contribute, under certain circumstances, to improve children's well-being and level of physical health. ${ }^{110,111}$

It is essential to underscore, through the many evidences presented, the existence of diversity in the developmental processes and responses to divorce, given that, according to the data under investigation, it is not adequate to state that a single pattern of adjustment to divorce exists. Granted, children of divorced parental dyads are, in most cases, faced with more stressors and show more problems in family interaction and personal adaptation than children from intact families. However, most of these children are resilient and able to cope with the impact of divorce over their lives, thus returning to the levels of adaptation they presented before the stress-inducing event. In some cases, parental divorce may even operate as a lever for more beneficial developmental pathways, thus promoting optimal development. 112

\section{Acknowledgements}

The authors are thankful to Patrícia Silva, biologist and PhD student in Clinical Psychology in the Neuropsychophysiology Laboratory of the School of Psychology at Universidade do Minho, for the orthographic adaptation of the original article to Brazilian Portuguese.

\section{References}

1. Levine S, Haltmeyer GC, Kaas GG, Penenberg VH. Physiological and behavioral effects of infantile stimulation. Physiol Behav. 1967;2:55-63.

2. Bloch M, Peleg I, Koren D, Aner H, Klein E. Long-term effects of early parental loss due to divorce on the HPA axis. Horm Behav. 2007;5:516-23.

3. Luecken L, Lemery K. Early caregiving and physiological stress responses. Clin Psychol Rev. 2004;24:171-91.

4. Meinlschmidt G, Heim C. Decreased cortisol awakening response after early loss experience. Psychoendocrinology. 2005;30:568-76.

5. Hetherington EM, Kelly J. For better or for worse: divorce reconsidered. New York: Norton; 2002.

6. Clarke-Stewart A, Brentano C. Divorce, causes and consequences. New Haven: Yale University Press; 2006.

7. Amato PR. Children of divorce in the 1990s: an update of the Amato and Keith (1991) meta-analysis. J Fam Psychol. 2001;15:355-70.

8. Amato PR, Keith B. Parental divorce and the well-being of children: a meta-analysis. Psychol Bull. 1991;110:26-46.

9. Troxel WM, Matthews KA. What are the costs of marital conflict and dissolution to children's physical health? Clin Child Fam Psychol Rev. 2004;7:39-57.

10. Hetherington EM. Divorce and the adjustment of children. Pediatr Rev. 2005;26:163-9.

11. Hetherington EM, Bridges M, Insabella GM. What matters? what does not? five perspectives on the association between marital transitions and children's adjustment. Am Psychol. 1998;53:167-84.

12. Hetherington EM, Stanley-Hagan M, Anderson ER. Marital transitions: a child's perspective. Am Psychol. 1989;44:303-12.

13. Kelly J, Emery R. Children's adjustment following divorce: risk and resilience perspectives. Family Relations. 2003;52:352-62.

14. Sobolewski J, Amato P. Parents' discord and divorce, parent-child relationships and subjective well-being in early adulthood. Social Forces. 2007;85:1105-24.

15. Carlson M, Corcoran M. Family structure and children's behavioral and cognitive outcomes. J Marriage Fam. 2001;63:779-92.

16. Teachman J, Paach K. Financial impact of divorce on children and their families. Future Child. 1994;4:63-83.

17. Fischer T. Parental divorce and children's socio-economic success: conditional effects of parental resources prior to divorce, and gender of child. Sociology. 2007;41:475-95.

18. Emery RE. Interparental conflict and the children of discord and divorce. Psychol Bull. 1982;92:310-30.

19. Wolchik SA, Wilcox KL, Tein JY, Sandler IN. Maternal acceptance and consistency of discipline as buffers of divorce stres sors on children's psychological adjustment problems. J Abnorm Child Psychol. 2000;28:87-102. 
20. Campana K, Henderson S, Stolberg A, Schum L. Paired maternal and parental parenting styles, child custody and children's emotional adjustment to divorce. J Divorce \& Remarriage. 2008;48:1-20.

21. Kelly JB. Children's adjustment in conflicted marriage and divorce: a decade review of research. J Am Acad Child Adolesc Psychiatry. 2000;39:963-73.

22. Feinberg $M$. The internal structure and ecological context of coparenting: a framework for research and intervention. Parent Sci Pract. 2003;3:85-131.

23. Macie KM. Influence of co-parenting and marital status on young adult adjustment [tese]. Virginia: Virginia Commonwealth University; 2002.

24. Maccoby E, Depner C, Mnookin R. Coparenting in the second year after divorce. J Marriage Fam. 1990;52:141-55.

25. Hetherington EM. An overview of the Virginia longitudinal study of divorce and remarriage with a focus on early adolescence. J Fam Psychol. 1993;7:39-56.

26. Hetherington EM. The influence of conflict, marital problem solving and parenting on children's adjustment in nondivorced, divorced and remarried families. In: Clarke-Stewart A, Dunn J, editores. Families count - effects on child and adolescent development. New York: Cambridge University Press; 2006. p.: 203-37

27. McIntosh JE. Enduring conflict in parental separation: pathways of impact on child development. J Fam Studies. 2003;9:63-80. http://jfs.e-contentmanagement.com/archives/vol/9/issue/1/ article/91/enduring-conflict-in-parental-separation. Acesso: 23/09/2009.

28. Buchanan $\mathrm{C}$, Heiges $\mathrm{K}$. When conflict continues after the marriage ends: effects of postdivorce conflict on children. In: Grych $\mathrm{H}$, Fincham $\mathrm{F}$, editores. Interparental conflict and child development. New York: Cambridge University Press; 2001. p.: 337-62.

29. Schoppe S, Mangelsdorf S, Frosch C. Coparenting, family process, and family structure: implications for preschoolers' externalizing behavior problems. J Fam Psychol. 2001;15:526-45.

30. Langrock, AM, Compas BE, Keller G, Merchant, MJ, Copeland ME. Coping with the stress of parental depression: parents' reports of children's coping, emotional, and behavioral problems. J Clin Child Adolesc Psychol. 2002;31:312-24.

31. Barber B, Demo D. The kids are alright (at least most of them): links between divorce and dissolution and child well-being. In: Fine M, Harvey JP, editores, Handbook of divorce and relationship dissolution. Mahwah: Lawrence Erlbaum Associates, Publishers; 2006. p.: 289-331.

32. Lovejoy MC, Graczyk PA, O'Hare E, Neuman G. Maternal depression and parenting behavior: a meta-analytic review. Clin Psychol Rev. 2000;20:561-92.

33. Pilowsky D, Wickramaratne $P$, Nomura $Y$, Weissman $M$. Family discord, parental depression, and psychopathology in offspring: 20-year follow up. J Am Acad Child Adolesc Psychiatry. 2006;45:425-60.

34. Kerig P. Revisiting the construct of boundary dissolution: a multidimensional perspective. In: Kerig $P$, editor. Implication of parent-child boundary dissolution for developmental psychopathology. New York: Routledge; 2006. p. 5-42.

35. Peris T, Emery R. Redefining the parent-child relationship following divorce: examining the risk for boundary dissolution. In: Kerig $\mathrm{P}$, editor. Implication of parent-child boundary dissolution for developmental psychopathology. New York: Routledge; 2006. p. 169-90.

36. Noller P, Feeney J, Sheehan G, Darlington Y, Rogers C. Conflict in divorcing and continuosly married families: a study of marital, parental-child and sibling relationships. J Divorce \& Remarriage. 2008;49:1-24.

37. Sturge-Apple ML, Davies PT, Cummings EM. Impact of hostility and withdrawal in's interparental conflict on parental emotional unavailability and children's adjustment difficulties. Child Dev. 2006;77:1623-41.
38. Bradford $\mathrm{K}$, Vaughn $\mathrm{L}$, Barber $\mathrm{B}$. When there is conflict: interparental conflict, parent-child conflict, and youth problem behaviors. J Fam Issues. 2008;29:780-805.

39. Grych J. Interparental conflict as a risk factor for child maladjustment: implications for the development of prevention programs. Fam Court Rev. 2005;43:97-108.

40. Sturge-Apple $M$, Davies $P$, Winter $M$, Cummings $E$, Schermerhorn A. Interparental conflict and children's school adjustment: the explanatory role of children's internal representations of interparental and parent-child relationships. Dev Psychol. 2008;44:1678-90.

41. Johnston J. Developing and testing a group intervention for families at impasse. California: Center for the Family in Transition; 1998.

42. Schick A. Behavioral and emotional differences between children of divorce and children from intact families: clinical significance and mediating processes. Swiss J Psychol. 2002;61:5-14

43. Biblarz T, Gottainer G. Family structure and children's success: a comparison of widowed and divorced single-mother families. J Marriage Fam. 2000;62:533-48

44. Bertram A. The relationship of parent involvement and postdivorce adjustment to the academic achievement and achievement motivation of school-aged children [tese]. Stillwater: Oklahoma State University; 2006.

45. Jeynes W. Effects of parental involvement and family structure on the academic achievement of adolescents. Marriage Fam Rev. 2005;37:99-116.

46. Landsford J, Malone P, Castellino D, Dodge K, Pettit G, Bates J. Trajectories of internalizing, externalizing, and grades for children who have and have not experienced their parents' divorce or separation. J Fam Psychol. 2006;20:292-301.

47. Turk J, Graham P, Verhulst F. Child and adolescent psychiatry: a developmental approach. Oxford: Oxford University Press; 2007.

48. Gold PW, Goodwin FK, Chrousos GP. Clinical and biochemical manifestations of depression. Relation to the neurobiology of stress (2). N Engl J Med. 1988;319:413-20.

49. Dozier M, Manni M, Gordon MK, Peloso E, Gunnar MR, StovallMcClough KC, et al. Children's diurnal production of cortisol: an exploratory study. Child Maltreat. 2006;11:189-97.

50. Niehoff D.Psicobiologia de la Violencia. Madrid: Ariel; 2000.

51. Cicchetti D, Rogosch FA. The impact of child maltreatment and psychopathology on neuroendocrine functioning. Dev Psychopathol. 2001;13:783-804.

52. Schiefelbein V, Susman E. Cortisol levels and longitudinal cortisol change as predictors of anxiety in adolescents. Journal of Early Adolescence. 2006;26:397-413.

53. Brown S. Family structure and child well-being: the significance of parental cohabitation. J Marriage Fam. 2004;66:351-67.

54. Cummings EM, Davies PT. Children and marital conflict: the impact of family dispute and resolution. New York: Guilford Press; 1994.

55. Malone PS, Lansford JE, Castellino DR, Berlin LJ, Dodge KA, Bates JE, et al. Divorce and child behavior problems: applying latent change score models to life event data. Structural Equation Modeling. 2004;11:401-23.

56. Graham Y, Heim C, Goodman S, Miller A, Nemeroff C. The effects of neonatal stress on brain development: implications for psychopathology. Dev Psychopathol. 1999;11:545-65.

57. Gunnar M, Quevedo K. The neurobiology of stress and development. Annu Rev Psychol. 2007;58:145-73.

58. Schneiderman N, Ironson G, Siegel SD. Stress and health: psychological, behavioral, and biological determinants. Annu Rev Clin Psychol. 2005;1:607-28. 
59. Sandi C, Calés L. Estrés: consequências psicológicas, fisiológicas y clínicas. Madrid: Sanz y Torres, 2000.

60. Selva J. Psicofisiologia. Madrid: Sinteses Psicologia; 1995.

61. Ramos R. Acontecimentos de vida na infância e percepção de stresse na adultez [dissertação]. Braga: Universidade do Minho; 2004.

62. Vyas A, Mitra R, Shankaranarayana Rao BS, Chattarji S. Chronic stress induces contrasting patterns of dendritic remodeling in hippocampal and amygdaloid neurons. J Neurosci. 2002;22:6810-8.

63. Lucassen P, Vollmann-Honsdorf G, Gleisberg M, Czéh B, de Kloet R, Fuchs E. Chronic psychosocial stress differentially affects apoptosis in hippocampal subregions and cortex of the adult tree shrew. Eur J Neurosci. 2001;14:161-6.

64. Kim JJ, Diamond DM. The stressed hippocampus, synaptic plasticity and lost memories. Nat Rev Neurosci. 2002;3:453-62.

65. Boyer P. Do anxiety and depression have a common pathophysiological mechanism? Acta Psychiatr Scand Suppl. 2000;(406):24-9.

66. King SL, Hegadoren KM. Stress hormones: how do they measure up? Biol Res Nurs. 2002;4:92-103.

67. Felten SY, Olschowka J. Noradrenergic sympathetic innervation of the spleen: II. Tyrosine hydroxylase (TH)-positive nerve terminals form synapticlike contacts on lymphocytes in the splenic white pulp. J Neurosci Res. 1987;18:37-48.

68. Kiecolt-Glaser J, Garner W, Speicher C, Penn G, Holliday J, Glaser R. Psychosocial modifiers of immunocompetence in medical students. Psychosom Med. 1984;46:7-14.

69. Glaser R, Rice J, Sheridan J, Fertel R, Stout J, Speicher C, et al. Stress-related immune suppression: health implications. Brain Behav Immun. 1987;1:7-20.

70. Glaser R, Pearson GR, Bonneau RH, Esterling BA, Atkinson C, Kiecolt-Glaser JK. Stress and the memory T-cell response to the Epstein-Barr virus in healthy medical students. Health Psychol. 1993;12:435-42.

71. Glaser R, Rice J, Speicher CE, Stout JC, Kiecolt-Glaser JK. Stress depresses interferon production by leukocytes concomitant with a decrease in natural killer cell activity. Behav Neurosci. 1986; 100:675-8.

72. Esterling A, Anton H, Fletcher A, Margulies S, Schneiderman N. Emotional disclosure through writing or speaking modulates latent Epstein-Barr virus antibody titers. J Consult Clin Psychol. 1994;62:130-40.

73. Maia AC. Emoções e sistema imunológico: um olhar sobre a psiconeuroimunologia. Psicologia, teoria, investigação e prática. 2002;2:2007-225.

74. Herbert TB, Cohen S. Depression and immunity: a meta-analytic review. Psychol Bull. 1993;13:472-86.

75. Fleshner M, Laudenslager ML. Psychoneuroimmunology: then and now. Behav Cogn Neurosci Rev. 2004;3:114-30.

76. Riley AW, Finney JW, Mellits ED, Starfield B, Kidwell S, Quaskey S, et al. Determinants of children's health care use: an investigation of psychosocial factors. Med Care. 1993;31:767-83.

77. Luecken LJ, Fabricius WV. Physical health vulnerability in adult children from divorced and intact families. J Psychosom Res. 2003;55:221-8.

78. Fabricius WV, Luecken LJ. Postdivorce living arrangements, parent conflict, and long-term physical health correlates for children of divorce. J Fam Psychol. 2007;21:195-205.

79. Rahkonen O, Lahelma E, Huuhka M. Past or present? Childhood living conditions and current socioeconomic status as determinants of adult health. Soc Sci Med. 1997;44:327-36.

80. Ballard ME, Cummings EM, Larkin K. Emotional and cardiovascular responses to adult's angry behavior and to challenging tasks in children of hypertensive and normotensive parents. Child Dev. 1993;64:500-15.

81. El-Sheikh M, Harger J, Whitson SM. Exposure to interparental conflict and children's adjustment and physical health: the moderating role of vagal tone. Child Dev. 2001;72:1617-36.
82. Flinn MV, England BG. Childhood stress and family environment. Cur Anthropol. 1995;36:854-66.

83. Salomon K, Matthews K, Allen M. Patterns of sympathetic and parasympathetic reactivity in a sample of children and adolescents. Psychophysiology. 2000;37:842-9.

84. Luecken LJ. Childhood attachment and loss experiences affect adult cardiovascular and cortisol function. Psychosom Med. 1998;60:765-72.

85. Saler L, Skolnick N. Childhood parental death and depression in adulthood: roles of surviving parent and family environment. Am J Orthopsychiatry. 1992;62:504-16.

86. Fernald L, Burke H, Gunnar M. Salivary cortisol levels in children of low-income women with high depressive symptomatology. Dev Psychopathol. 2008;20:423-36.

87. Field T, Hernandez-Reif M, Diego M, Schanberg S, Kuhn C. Cortisol decreases and serotonin and dopamine increase following massage therapy. Int J Neurosci. 2005;115:1397-413.

88. Young EA, Vazquez D, Jiang $H$, Pfeffer CR. Saliva cortisol and response to dexamethasone in children of depressed parents. Biol Psychiatry.2006;60:831-6.

89. Ashman SB, Dawson G, Panagiotides H, Yamada E, Wilkinson CW. Stress hormone levels of children of depressed mothers. Dev Psychopathol. 2002;14:333-49.

90. de Jong MJ. Attachment, individuation, and risk of suicide in late adolescence. J Youth Adolesc. 1992;21:357-73.

91. D'Onofrio BM, Turkheimer E, Emery RE, Slutske WS, Heath AC, Madden PA, et al. A genetically informed study of the processes underlying the association between parental marital instability and offspring adjustment. Dev Psychol. 2006;42:486-99.

92. Tucker JS, Friedman HS, Schwartz JE, Criqui MH, TomlinsonKeasey C, Wingard DL, et al. Parental divorce: effects on individual behavior and longevity. J Pers Soc Psychol. 1997;73:381-91.

93. Aro HM, Palosaari UK. Parental divorce, adolescence, and transition to adulthood: a follow-up study. Am J Orthopsychiatry. 1992;62:421-9.

94. Barber N. Sex differences in dispositions towards kin, security of adult attachment, and socio-sexuality as a function of parental divorce. Evol Hum Behav. 1998;19:125-32.

95. Sartor CE, Lynskey MT, Heath AC, Jacob T, True W. The role of childhood risk factors in initiation of alcohol use and progression to alcohol dependence. Addiction. 1007;102:216-25.

96. Wolfinger $\mathrm{NH}$. The effects of parental divorce on adult tobacco and alcohol consumption. J Health Soc Behav. 1998;39:254-69.

97. Paxton $\mathrm{R}$, Valois $\mathrm{R}$, Drane $\mathrm{W}$. Is there a relationship between family structure and substance use among public middle school students? J Child Fam Stud. 2007;16:593-603.

98. Mota DM, Barros AJ. Toilet training: methods, parental expectations and associated dysfunctions. J Pediatr (Rio J). 2008;84:9-17.

99. Jansson UB, Sillen U, Hellstrom AL. Life events and their impact on bladder control in children. J Pediatr Urol. 2006;3:171-7.

100. Sirvalin-Ozen D. Impacts of divorce on the behavior and adjustment problems, parenting styles, and attachment styles of children: literature review including Turkish studies. J Divorce \& Remarriage. 2005;42:127-51.

101. Novak M, Ahlgren C, Hammarström A. A life-course approach in explaining social inequity in obesity among young adult men and women. Int J Obes (Lond). 2006;30:191-200.

102. Kilpeläinen $M$, Koskenvuo $H$, Helenius $H$, Terho E. Stressful life events promote the manifestation of asthma and atopic diseases. Clin Exp Allergy. 2002;32:256-63.

103. Figueiredo B, Bifulco A, Pacheco A, Costa R, Magarinho R. Teenage pregnancy, attachment style, and depression: a comparison of teenage and adult pregnant women in a Portuguese series. Attach Hum Dev. 2006; 8:123-38.

104. Doucet J, Aseltine Jr RH. Childhood family adversity and the quality of marital relationships in young adulthood. J Soc Pers Relatsh. $2003 ; 20: 818-42$. 
105. Leininger LJ, Ziol-Guest KM. Reexamining the effects of family structure on children's acess to care: the single-father family. Health Serv Res. 2008;43:117-33.

106. Maier EH, Lachman ME. Consequences of early parental loss and separation for health and well-being in midlife. Int J Behav Develop. 2000;24:183-9.

107. Huurre $\mathrm{T}$, Junkkari $\mathrm{H}$, Aro $\mathrm{H}$. Long-term psychosocial effects of parental divorce: a follow-up study from adolescence to adulthood. Eur Arch Psychiatry Clin Neurosci. 2006;256:256-63.

108. Clarke-Stewart KA, Vandell DL, McCartney K, Owen MT, Booth C. Effects of parental separation and divorce on very young children. J Fam Psychol. 2000;14:304-26.

109. Pruett MK, Williams TY, Insabella G, Little TD. Family and legal indicators of child adjustment to divorce among families with young children. J Fam Psychol. 2003;17:169-80.

110. Crosnoe R, Elder G. Family dynamics, supportive relationships, and educational resilience during adolescence. J Fam Issues. 2004;25:571-602.
111. Hagerty B, Williams R, Oe H. Childhood antecedents of adult sense of belonging. J Clin Psychol. 2002;58:793-801.

112. Morgado B, Rodríguez G. Divorcio y ajuste psicológico infantil: primeras respuestas a algunas preguntas repetidas. Apuntes de Psicología. 2001;19:387-402.

\author{
Correspondence: \\ Bárbara Figueiredo \\ Departamento de Psicologia \\ Universidade do Minho \\ Campus de Gualtar \\ 4710-057 - Braga - Portugal \\ Tel.: +351 (253) 604.223 \\ Fax: +351 (253) 604.221 \\ E-mail: bbfi@iep.uminho.pt
}

